University of Rhode Island

DigitalCommons@URI

The Rhode Island Current Conditions Index

Economics

$1-2016$

\title{
Rhode Island Current Conditions Index - January 2016
}

Leonard Lardaro

University of Rhode Island, lardaro@uri.edu

Follow this and additional works at: https://digitalcommons.uri.edu/ricci

Part of the Econometrics Commons

Terms of Use

All rights reserved under copyright.

\section{Recommended Citation}

Lardaro, Leonard, "Rhode Island Current Conditions Index -- January 2016" (2016). The Rhode Island Current Conditions Index. Paper 145.

https://digitalcommons.uri.edu/ricci/145

This Article is brought to you for free and open access by the Economics at DigitalCommons@URI. It has been accepted for inclusion in The Rhode Island Current Conditions Index by an authorized administrator of DigitalCommons@URI.For more information, please contact digitalcommons-group@uri.edu. 


\title{
CURRENT CONDITIONS
}

LEONARD LARDARO, URI

\author{
Available Online: http:/ / www .Ilardaro.com/ current.htm \\ Blog: http:/ / rieconomy.blogspot.com \\ Twitter: @ladardo
}

VOL XXIHI

NUMBER 2

JAN 2016
While we continued to hope throughout the fourth quarter of 2015 that the slowing of economic activity we were experiencing would soon moderate, the revised (i.e., rebenchmarked) labor market data has rather abruptly informed us that things were not quite as rosy as what we had been led to believe. Payroll employment, or the number of jobs by Rhode Island firms, was actually revised higher in the new data starting in July of 2014. That's about all of the good news. Even though employment was revised higher, its rate of growth has been both lower and slowing since September of last year. Worse yet, our original data indicated accelerating growth at the end of 2015. The revised data show exactly the opposite: instead of year-over-year employment growth approaching two percent, it actually fell below one percent!

Then there is the household survey, which gives us data on the Labor Force, Resident Employment, and the Unemployment Rate. Originally, we had been led to believe that our Labor Force had begun to increase on a year-over-year basis since May of 2015. The revised data show that Labor Force either declined or remained unchanged for all of 2015, which led to downward revisions to the Current Conditions Index values throughout the second half of 2015. Sadly, the decline in our Labor Force continued in January of 2016 as well. As for our Unemployment Rate, the statistic that everyone here pays far too much attention to, it was revised higher since September of

\begin{tabular}{|l|r|r|}
\hline \multicolumn{2}{|c|}{ CCI Indicators - \% Change } \\
\hline Government Employment & -0.7 \\
\hline US Consumer Sentiment & -6.1 & \\
\hline Single-Unit Permits & 34.6 & Y \\
\hline Retail Sales & -0.9 & \\
\hline Employment Services Jobs & 2.1 & Y \\
\hline Priv. Serv-Prod Employment & 0.8 & Y \\
\hline Total Manufacturing Hours & 1.1 & Y \\
\hline Manufacturing Wage & -4.5 & \\
\hline Labor Force & -0.5 & \\
\hline Benefit Exhaustions & -21.7 & Y \\
\hline New Claims & $-\mathbf{8 . 7}$ & Y \\
\hline Unemployment Rate (change) & -1.2 & Y \\
\hline \multicolumn{2}{|c|}{ Y = Improved Value } \\
\hline
\end{tabular}

last year. For January, it fell on a monthly basis from its upwardly revised December value. So, Rhode Island begins 2016 with higher levels, albeit slowing growth rates, in payroll employment, and an Unemployment Rate that is falling from its upwardly revised level. For almost all of 2015, the Current Conditions Index was stuck at 67 , a middling value. Finally, we were only able to beat year-earlier $\mathrm{CCl}$ values six times last year. In other words, we are really slowing as national momentum moderates.

For January, the Current Conditions Index rose from its downwardly revised December value of 50 to 58 . There was some good news for January. While the recent weak $\mathrm{CCl}$ values largely reflect the fact that our negatives have been growing relative to our positives, four of the five leading indicators contained in the $\mathrm{CCl}$ improved. Unlike past months, where much of our weakness has been concentrated in our goods-producing sector, for J anuary, weakness was fairly widespread.

Looking first at the four improving leading indicators, Total Manufacturing Hours, a measure of manufacturing sector strength, rose by 1.1 percent in January, its first improvement in a year (versus four with the prior data). Along with this, the Manufacturing Wage declined yet again, this month by 4.5 percent. New home construction, in terms of Single-Unit Permits, rose by 34.6 percent in January, only its fifth improvement since last June, aided partly by an easy comp a year ago. Employment Service Jobs, which includes temporary employment and is a prerequisite to employment growth, rose by 2.1 percent, among its slower growth rates in some time. Finally, New Claims, a leading labor market indicator that reflects layoffs, fell by 8.7 percent in January, assisted by a relatively easy comp one year ago. The lone non-improving leading indicator, US Consumer Sentiment, fell for only its second time in over a year, by $6.1 \%$ percent.

Retail Sales actually declined in January (-0.9\%), following nineteen consecutive improvements. Private Service-Producing Employment, an indicator whose actual growth had been slowing, rose by only 0.8 percent in January. Government Employment fell again $(-0.7 \%)$. Benefit Exhaustions, which reflects longer-term unemployment, declined by 21.7 percent relative to last year. Our Labor Force never had the recent yearly uptrend contained in the original data. Worse yet, it has continued to decline on both a monthly and yearly basis in January, falling back to its level in the second half of 2002! So, Rhode Island's Unemployment Rate continues to fall for the wrong reasons.

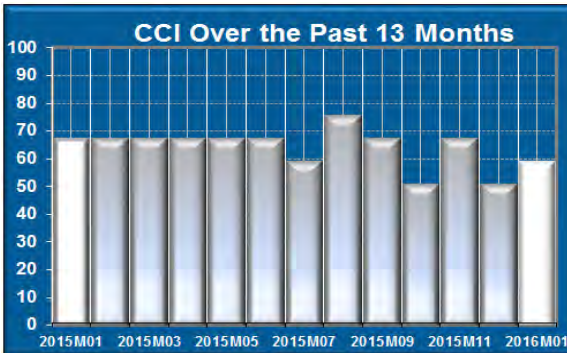

DLT J AN Employment (SA,Y/Y)

\section{THE BOTTOM LINE}

Rhode Island began 2016 in much the same way it ended 2015: a slowing economy. What we only found out lately is that we are slowing from less robust levels of economic activity than existing data had led us to believe. Just last month, everyone was celebrating a fall in our jobless rate to 5.1 percent. Now we discover that our rates were actually higher at the end of 2015 and our Labor Force continually declined. What could be worse? Even though payroll employment was revised higher (since July of 2014), we ended 2015 with slowing rates of job growth, moving to below one percent growth! Let's hope that the national economy boosts our momentum. Soon!

\begin{tabular}{|l|l|l|l|l|l|l|l|l|l|l|l|l|l|}
\hline & & Jan & Feb & Mar & Apr & May & J un & J ul & Aug & Sep & Oct & Nov & Dec \\
\cline { 2 - 13 } & 2015 & $67 \uparrow$ & $67 \uparrow$ & 67 & $67 \uparrow$ & 67 & $67 \downarrow$ & $58 \downarrow$ & $75 \downarrow$ & $67 \downarrow$ & $50 \downarrow$ & $67 \downarrow$ & $50 \downarrow$ \\
\cline { 2 - 12 } & 2016 & 58 & & & & & & & & & & & \\
\hline
\end{tabular}

